\title{
Six Problems in Levinas's Philosophy
}

\author{
Alphonso Lingis
}

Emmanuel Levinas introduced a new conception of sensibility. The primitive form of sensibility is the impersonal vigilance in insomnia that watches the beginningless endless continuity of the night. We awaken to find ourselves in depths of light, colour, sonority, texture, warmth and cold. The sensibility for the sensuous is not a synoptic receptivity for a multiplicity of sense data; instead light, darkness, chromatic density, sonority, warmth and cold are surfaceless depths in which the sensuous body is immersed. Sensibility is not intentional; it is an involution in depths.

Levinas describes the sensible and postural relationship to the supporting depth of the ground. Our life alternates between standing on the ground, establishing a here, and repose and sleep on the ground, giving over to the supporting and sustaining earth the responsibility of maintaining oneself in life. Space is fundamentally structured by the retreat into a sphere of the home, zone of rest and tranquility, and the outlying environment in which we move, supported by the ground that supports the things in their places.

Out of the elemental depths things take form. They are substances, subsistent solids enclosed within contours. Things can be detached and manipulated because they are substances, solids that hold themselves together. Things are not then from the first implements, Zeuge, formed in manipulation and usage. The instrumental features of things are transitory accidental 
properties; a hammer can be used to drive in the nails, but also to lever up the refrigerator and to prop open the door.

Things are not from the first implements, means, but ends, goods, given to enjoyment. Things attract us with their intrinsic goodness. The things about us attract desire, which ends in them, is satisfied, contented with them. We breathe for the sake of breathing the good air, we eat in savouring the goodness of terrestrial nourishments, we drink in enjoying the tang and bouquet of the wine.

\section{Constitutive Analysis}

However, Levinas casts these penetrating descriptions in a constitutive phenomenology that explains how phenomena are constituted in the perception and usage of a subject.

We awaken in the light and its illuminating work is naturally understood; it encompasses a field of things and presents them as a field; "in this sense [the field] is already like the product of a synthesis" (Existence 41). Light appears centred where we are, Levinas writes, but then he says it appears as coming from us. In the light with which we see, the things emerge as brought forth by our power, the power of our look that instantaneously traverses the light; as things emerge they are already ours, possessed. Intention, which from the first grasps the desirability, the attractiveness of things, is possession at a distance. "Illuminated by the light, [things] have meaning, and thus are as though they came from me" (Existence 85). They are from the first appropriated, perceived as our possessions. They emerge as ordered forth by our freedom" (Existence 41). ${ }^{1}$

We, for our part, object that the light appears to come from the sun or from lamps, or it is there as an unbounded medium without contours in which we find ourselves immersed. The light 
illuminates things far beyond the range of our vision, things visible to other humans and countless individuals of other species, and things visible to no one, things visible in themselves.

The fact that things appear to me in the light does not mean that they appear to exist through me and for me. The things appear as substances clothed and enclosed by their contours, indifferent to me. When we look out of the train window upon the luminous landscape, the image we take of it, already fading out, makes us keenly aware of its unpossessable reality.

Levinas explains that things take form in the elements by my detaching them, appropriating them, making them meubles-furnishings. I contract the identity of a practical agent and dweller in a home by constituting the environment as a layout of furnishings. I and my environment of things-meubles form a totality, the sphere of "the Same."

Here Levinas's phenomenology becomes idealist and positivist. The sense of things is constituted by the subject that appropriates them; their very reality appears "as though they came from me." They exist for my enjoyment, and lay no claims on me.

This constitutive analysis fails to recognize that the things do not appear to owe their existence as things to my appropriative acts; they appear to exist in themselves as subsistent substances and organisms. Their character as meubles, my possessions, appears as a transitory accidental trait.

Our existence as conscious organisms appears to us to depend on the prior and independent existence of the earth and its geological composition, climate, and ecosystems. A sequoia, an Oryx, a starfish appear to exist with their own internal and external forms prior to and independent of my consciousness of them. We see that other species perceive what we perceive, that our sensibility and perception are similar to the sensibility and perception of other 
species, who perceive the things of their environments as exterior, independent of them, and as real as they are. ${ }^{2}$

\section{Someone Other in his Appeals and Demands}

Levinas's analysis of the act of facing is an essential contribution to philosophy. In facing me someone does not simply expose himself to my perception and interpretation; he or she appeals to me and puts demands on me. Someone faces to speak to me; speech is not only indicative, informative, but also vocative and imperative. Levinas defines a specific sensibility for someone who faces; in facing me the other exposes his or her vulnerable and mortal surfaces, wounds, scars, wrinkles. These are not simply observed; they afflict me from the start, my eyes flinch, feeling the pain in themselves. They stir in me the impulse to respond. I find myself responsible before the other for who I am and what I am doing, and responsible for the needs and lacks of the other.

What is the sense that the one who faces me is not just another one like me, but other than me and other than my environment? For Levinas it the recognition of vulnerability and mortality in him or her, the recognition of needs and wants. But, we object, needs and wants are seen on the positive plenitude of an organism and are intermittent and superficial. It is because we recognize and acknowledge the positive reality of someone before us that we recognize the claim his appeal and demand put on us.

When someone faces us, we see someone in whom nature has achieved something: we see hale and hearty physical heath and vigor, vibrant sensibility, beauty. We see someone who has done something with his or her life, protected and nourished, built, repaired, restored, rescued. We see someone who has cared for a sick relative, maintained a farm, been a devoted 
teacher, is a loyal friend. We see someone who has not achieved anything materially, but who knows that he or she is a good person, steadfast, open-minded, with a good head and a good heart, has dared to break the rules and make mistakes, has a sense of his or her worth. We see facing us someone who has suffered the worst oppressions of the social system and the worst destructions wrought by disease or nature and who has been able to endure suffering and awaits death with lucidity and courage. We see someone who has the vitality to laugh over absurdities and his or her own failures, has the strength to weep over the loss of a lover and over the death of a child in another land.

Is it not the particular and intrinsic goodness of the life that approaches us that gives force to his or her contestation of our personal concerns?

\section{Infinity}

To see a caterpillar, a squirrel, a water lily is to see what it needs to exist, and to see its lacks and wounds. It is also to sense what powers stir in our sensibility and limbs that can answer to its needs. A wounded sheep in my flock, an orphaned baby squirrel - their needs and wants are exposed and afflict me.

Levinas claims that what is different in the human who faces me from a being of another species is that when I respond to the needs and wants of someone of my species, he or she opens upon further needs and wants without end. In responding I find the unendingness, infinition, of his or her wants and needs. ${ }^{3}$ The fundamental relationship between humans is their unending dependency on me. ${ }^{4}$ 
I may well then turn to myself and find that it is important to be concerned with myself and care for myself. But this obligation to care for myself, Levinas affirms, derives from my obligation to respond to the needs of others. ${ }^{5}$

But we think that a human organism, like that of other species, is a locus of production of excess energies. Human needs and wants are intermittent and superficial (not the core reality), and satisfiable. Levinas had acknowledged that the needs of a living organism are finite; they end in terrestrial goods and nourishments. Our appetite ends in the enjoyment of spring water and forest berries and wine. Desires are sincere: hungers end in the enjoyment of food and are not relayed unto an indefinite succession of further wants. If this is true of me, as Levinas argues, is it not also true of the others?

I am responsible for my child's vulnerable body, but it is not the locus of unending wounds that I have to heal; his or her body heals itself. I have to supply for his or her needs, which are limited and satisfiable. Until the time when he or she can, and surely will want to, supply for them himself or herself.

\section{God in the Other}

The unendingness, infinition, of appeals and demands put on me opens the dimension of infinity that Levinas names God. God is not to be conceptualized as a supreme entity within the world or beyond the world, but as "otherwise than being." Negative as absent from the being of the world, but positive as the force that appeals and demands, this "otherwise than being" proves very difficult to formulate.

In making the alterity of God constitutive of the otherness (infinitely removed in the unendingness of his claims on me) of the one who faces me, does not Levinas effectively reduce 
the otherness between one who faces me and another who also faces me to mere differencedifference in time and place, difference between the empirical figure of want and need each presents? $?^{6}$

Further, in the measure that God is conceived as "the wholly Other,"7 constitutive of the otherness of every other human who faces me, the demand put on me loses its location in the midst of the common world and its determinateness. But a veridical response in language formulates a state of affairs in the environment open to my observation and the other's verification. A practical response to the appeal and demand that another presents enlists my resources and the resources at hand in my environment. A response, in words or in deeds, to the wholly Other can only be wholly indeterminate.

\section{Jewish Ethics}

Levinas presents his ethics as of unrestricted validity. But he also claimed it originated in the Jewish religious history. "We assume the unity of the consciousness of mankind claiming to be fraternal and one throughout time and space. It is Israel's history which has suggested this idea, even if mankind, now conscious of its oneness, allows itself to challenge Israel's vocation, its concrete universality" (Levinas, Nine 6).

But the impulse to respond to the needs and wants of others exists in every community and is formulated in the ethics of every community. Paleoanthropologist Alan Walker studied the first largely complete skeleton of Homo erectus ever found, of an adult female, identified as KNM-ER 1808, approximately 1.7 million years old. The bones were everywhere coated with a half-inch of pathological bone. Pathologists and radiologists at Johns Hopkins Medical School identified the cause to be hypervitaminosis A, which produces blood clots that had doubtless 
immobilized her and caused agonizing pain; yet she survived months until the clots ossified: “Alone, unable to move, delirious, in pain, 1808 wouldn't have lasted two days in the African bush much less the length of time her skeleton told us she had lived. Someone else brought her water and probably food ... And someone else protected her from hyenas, lions, and jackals on the prowl ..." (Walker and Shipman 165).

Indeed practical response to the needs of others of one's species is widespread across nature. Spiders, birds, and mammals risk their own lives to protect their young from predators. Bees, penguins, vultures, and antelopes share food found with others of their species. Numerous cases of individuals giving sustenance and assistance to members of other species have been documented. ${ }^{8}$ But Levinas separates ethics from all naturalism. What is distinctive to Levinas's ethics is the infinite extension of responsibility put on me, without reciprocal responsibility on the part of the others who face me, and its source in God.

\section{Ethics and the State}

The one who faces me is in turn faced by third parties, who face him with their appeals and demands. I am thus responsible, Levinas affirms, ultimately for the needs and wants of all humans.

This situation gives rise, Levinas says, to "calls for control, a search for justice, society and the State, comparison and possessions, thought and science, commerce and philosophy" (Otherwise [1999], 161).

For Levinas economic, social, juridical, and political institutions are based on an original ethical coexistence of a group of people and are established to protect and promote that ethical coexistence. But in fact there is a gaping abyss between the injunctions of Levinas's ethics and 
the economic, social, juridical, and political institutions that must arise from that ethics and must be governed by it. In the face-to-face encounter with another human, I find myself responsible for the unending succession of his needs and wants, and for all those who face him and all those who face those who face him. There is no reciprocity, which would presuppose a prior, more original, outside point of view before which I and the other would figure as equivalent. But as a citizen of the State, I find myself in the position of judge who subjects others to my orders and subjugates them. The essential means of the state are constraint and violence: taxes, expropriations, fines, punishment, exclusion, imprisonment, execution, and war.

Levinas affirmed that "now, under the given circumstances, as a state is the only form in which Israel - the people and the culture-can survive" (Righteous 81). He maintained silence about the political crimes committed in the establishment of Israel, its expansion, and its occupation of Palestine. What is at issue is not simply the empirical correctness and completeness of the information upon which his judgments were based, but the possibility that those who espouse an unrealizable ethics of absolute responsibility produce when in power, or acquiesce in, irresponsible and disproportionate state violence, and the ethics of absolute responsibility functions as ideology.

\section{Notes}

1 “To see is already to render the encountered object one's own, as drawn from one's own ground. In this sense 'transcendental constitution' is but a way of seeing in full clarity. It is a completion of vision" (Levinas, Time 64).

${ }^{2}$ See Lingis (Environment 2010) and also Lingis ("Sensibility” 2010).

3 "The more I answer the more I am responsible; the more I approach the neighbor with which I am encharged the further away I am. This debit which increases is infinity as an infinition of the infinite, as glory" (Levinas, Otherwise [1981] 93). 
4 "'It is as though I were responsible for his mortality, and guilty for surviving ... In proximity the absolutely other, the stranger whom I have 'neither conceived nor given birth to,' I already have on my arms, already bear, according to the Biblical formula, 'in my breast as the nurse bears the nurseling.' He has no other place, is not autochthonous, is uprooted, without a country, not an inhabitant, exposed to the cold and the heat of the seasons. To be reduced to having recourse to me is the homelessness or strangeness of the neighbor. It is incumbent" (Levinas, Otherwise [1981] 91); "I have not done anything and I have always been under accusation-persecuted. The ipseity, in the passivity without arche characteristic of identity, is a hostage. The world $I$ means here I am, answering for everything and for everyone" (114); "Witnessed, and not thematized, in the sign given to the other, the Infinite signifies out of responsibility for the other, out of the-one-for-the-other, a subject supporting everything, subject to everything, that is, suffering for everyone, but charged with everything, without having had to decide for this taking charge, which is gloriously amplified in the measure that it is imposed" (148).

5 "It is still out of my responsibility that my salvation has meaning ..." (Levinas, Otherwise [1981] 161).

6 "God is not involved as an alleged interlocutor: the reciprocal relationship binds me to the other man in the trace of transcendence, in illeity. The passing of God, of whom I can speak only by reference to this aid or this grace, is precisely the reverting of the incomparable subject into a member of society" (Levinas, Otherwise [1981] 158); “The subject is inspired by the Infinite, which as illeity, does not appear, is not present, has been always already past, is neither theme, telos nor interlocutor" (148).

7 "It makes the word God be pronounced, without letting 'divinity' be said. That would have been absurd, as though God were an essence (that is, as though he admitted the amphibology of being and entities), as though he were a process, or as though he admitted a plurality in the unity of a genus" (Levinas, Otherwise [1981] 162).

${ }^{8}$ See, among others, "Lionness adopts a baby antelope."

\section{Works Cited}

Levinas, Emmanuel. Otherwise than Being. Trans. Alphonso Lingis. The Hague: Martinus Nijhoff, 1981.

—. Time and the Other. Trans. Richard A. Cohen. Pittsburgh: Duquesne University Press, 1987.

- Nine Talmudic Readings. Trans. Annette Aronowicz. Bloomington: Indiana University Press, 1990. 
- Otherwise than Being or Beyond Essence. Trans. Alphonso Lingis. Pittsburgh: Duquesne University Press, 1999.

—. Existence and Existents. Trans. Alphonso Lingis. Pittsburgh: Duquesne University Press, 2001.

- Is it Righteous to Be? Interviews with Emmanuel Levinas. Ed. Jill Robbins. Stanford: Stanford University Press, 2001.

Lingis, Alphonso. "The Environment: A Critical Appreciation of Levinas's Analysis in Existence and Existents. "Levinas Studies Vol. 5 (2010): 65-81.

—. "Sensibility and Ethical Sensibility: A Critical Analysis of Levinas's Arguments" in MonoKL VIII-IX. Ed. Vollkan Celebi. Istanbul: MonoKL Publishing House, 2010. 33141.

“Lionness adopts a baby antelope.” YouTube. Web. 3 April 2012.

Walker, Alan and Shipman, Pat. The Wisdom of the Bones. New York: Knopf, 1996. 